\title{
Inevitability, contingency, and epistemic humility
}

\author{
Ian James Kidd \\ Department of Philosophy, Durham University, 50 Old Elvet, Durham, County Durham, DH1 3HN, United Kingdom
}

\section{A R T I C L E I N F O}

\section{Article history:}

Available online $\mathrm{xxx}$

\section{Keywords:}

Contingency;

Counterfactual history:

Epistemic humility;

Inevitability;

Hacking

\begin{abstract}
A B S T R A C T
This paper offers an epistemological framework for the debate about whether the results of scientific enquiry are inevitable or contingent. I argue in Sections 2 and 3 that inevitabilist stances are doubly guilty of epistemic hubris-a lack of epistemic humility-and that the real question concerns the scope and strength of our contingentism. The latter stages of the paper-Sections 4 and 5-address some epistemological and historiographical worries and sketch some examples of deep contingencies to guide further debate. I conclude by affirming that the concept of epistemic humility can usefully inform critical reflection on the contingency of the sciences and the practice of history of science.
\end{abstract}

(C) 2015 Elsevier Ltd. All rights reserved.

When citing this paper, please use the full journal title Studies in History and Philosophy of Science

\section{Introduction}

The purpose of this paper is to offer an epistemological analysis of the two broad stances on the question of whether the results of scientific enquiry are inevitable or contingent. ${ }^{1}$ My claim is that the answer to that question ought to be broadly contingentist and that our focus should therefore be on the related question of just how strong our contingentism ought to be. Specifically, I argue that 'inevitabilist' stances implicitly rely upon exaggerated estimations of our epistemic capacities: both in their historical claims and their main criticism of their contingentist rivals. First, the inevitabilists' claims about the inevitability of certain scientific results emerge as either trivial or epistemically unwarrantable. In fact, inevitabilism collapses into a form of contingentism. The second criticism is directed at the inevitabilists' primary criticism of their contingentist rivals, the 'put up or shut up objection', as Ian Hacking dubs it, and which I'll abbreviate to 'PUSU'. The putative choice reflected in this challenge-to 'put up' or 'shut up'-is, in fact, illusory, for on analysis, it emerges that it only allows the contingentist to 'shut up'. Since the objection therefore structurally excludes the

\footnotetext{
E-mail address: i.j.kidd@durham.ac.uk.

1 An excellent introduction to and survey of this debate is offered by Kinzel (2015).
}

possibility of a successful response because it relies upon untenable presuppositions, it ought to be rejected.

Taken together, these two criticisms indicate that the inevitabilist stance lacks epistemic humility, and is therefore hubristic (a pair of concepts explained in due course). It is partly because contingentism is humble, in a technical sense to be defined later in the paper, that we ought to embrace it. Indeed, it emerges that implicit claims to humility, and charges of hubris, are constant features of debates about the historical contingency of scientific enquiry, and indeed of debates about the sorts of epistemic ambitions to which we could reasonably aspire. ${ }^{2}$ This indicates that a due sense of epistemic humility requires us to adopt some form of contingentist stance, and so the real debate concerns the question of how contingentist we ought to be-and the paper closes, in Section 5 , by sketching two stronger forms of contingentism as a spur to further debate.

Let me begin, then, by characterising the 'inevitabilist' and 'contingentist' stances.

\section{Inevitabilism}

My characterisation of the inevitabilist stance will follow that offered by Hacking $(1999,2000)$. It consists of two claims, the

\footnotetext{
2 See, e.g., Langton (1998) and Moore (1997).
} 
former being taken from his writings, and the latter being my own addition, for reasons to be explained shortly.

(H1) Any result R of scientific investigation that we take to be correct can be described as inevitable if any other properlyresourced and rigorously-conducted investigation of the same subject matter would have contained or implied the same results.

(H2) H1 can be established in a sufficiently warranted manner.

Four points ought to be noted. First, contingency might creep into the inevitabilist position even at this initial stage, since the concepts and standards that define the resources and methods appropriate to scientific enquiry are subject to historical contingencies, a fact noted by Howard Sankey (2008) and David E. Cooper (2002: pp.199-200), among others. Many contemporary historians and sociologists of science have documented the variety of contingent social and cultural factors that shaped early debates about the epistemology and methodology of scientific enquiry, including postlapsarian theologies and shifting conceptions of the requisite moral and intellectual qualities of the natural philosopher. $^{3}$ Second, inevitabilism is best construed as an implicit commitment, perhaps as a component of a 'stance', rather than an explicit conviction. There are few 'card-carrying' inevitabilists, with a few honourable exceptions, including the physicists Sheldon Glashow and Steven Weinberg. ${ }^{4}$ Third, the idea that any result of scientific investigation is inevitable may occlude the idea that certain results become progressively inevitable as certain contingent conditions obtain. ${ }^{5}$ Such emergent inevitabilities complicate our efforts to define both inevitabilist and contingentist stances. Fourth, and most importantly, $\mathrm{H} 2$ implicitly incorporates a presupposition that plays a crucial role in debates about our capacity to determine the inevitability or contingency of the results of scientific investigation-call it $\mathrm{H} 2 \mathrm{a}$-namely, that it is possible that the inevitability of certain results could, either in principle or in practice, be both established, and be known to have been established.

These sub-claims are reflected in the two of the main components of the inevitabilists stance. The characteristic claims of the inevitabilist are, obviously enough, that one can determine, both in principle and in practice, the inevitability of certain scientific results. Otherwise inevitabilism can only gesture to, but never actually assert, the inevitability of whichever scientific results interest them-genes, say, or quarks - and that is a poor sort of inevitabilism. Similarly, the PUSU objection presupposes that it is possible, again in principle and in practice, for a contingentist to make good on their talk of the other ways that the history of scientific enquiry might have gone, by 'putting up' those alternative theories and results. Although the role of $\mathrm{H} 2 \mathrm{a}$ is less obvious here, there is-as I argue in Section 4-the same overestimation of our epistemic capacities.

Taken together, my two criticisms converge in the charge that inevitabilism lacks epistemic humility, and is, therefore, hubristic, in a double sense. First, it is hubristic to suppose that any individual or collective does or could possess the epistemic capacities required to perform the variety of tasks required to warrant claims about the inevitability of a given scientific result. Second, it assumes a hubristic conception of human capacities to suppose that anyone, the contingentist included, could actually produce entire alternative scientific theories and results, given the practical and epistemic

\footnotetext{
${ }^{3}$ See, e.g., Harrison (2007) and Shapin (2008).

${ }^{4}$ For a discussion and examples, see Soler (2008), §4.

5 A colleague of mine suggests that Allied victory was not inevitable in early 1939, but was by late 1944 .
}

realities of scientific enquiry. Since the inevitabilists stance, in both its claims and its main objection to rival contingentists, relies upon these sets of presuppositions, it is doubly hubristic, and therefore ought to be rejected. It is important to clarify the content of this objection: to say that a belief or doctrine is hubristic is not to say that it is false. Indeed, it may be true. The objection, rather, is that its truth or falsity either way cannot be determined, at least not by human enquirers. Strictly put, a belief or doctrine is hubristic when it is one that "only a creature with enhanced cognitive powers-not possessed by the person himself-would be warranted in holding' (Cooper, 2002, p. 167).

To advert to an example offered by Hacking, it may, in fact, be true to say that a successful science would inevitably 'arrive at or pass through something roughly equivalent to our present cosmology or cell biology' (2000, p. 59). The hubris lies, however, in the claim that we could, with sufficient warrant, ever actually determine this to be the case. Such a claim about the inevitability of, say, Big Bang cosmology may be true, or false, or might, instead, be a complex conditional, a position suggested by Hacking, Gregory Radick, and Léna Soler, among others. ${ }^{6}$ Though this more qualified form of inevitabilism has its merits, it buys them at the price of triviality-indeed, in making them, one comes 'close to an empty platitude' (Hacking, 2000, p. 66).

Once one begins to build in the range of conditions required to justify claims about conditional inevitability, the position rapidly collapses into a form of contingentism. Consider the claim that 'a quarky physics was inevitable, just as long as ...', where the ellipse stands for the diverse range of requisite conditional factors: the inevitabilist, in making this claim, effectively helps themselves to the inevitability of the questions, assumptions, concepts, methods, practices, disciplinary cultures, institutional structures-and so on-all of which are, of course, subject to their own contingencies. In such cases, then, one has what Paul Feyerabend impishly described as 'the success of a manoeuvre carried out in a void' (1993, p. 30)-that is, no success at all in any real sense.

This example helps to illustrate my criticism of claims that one could warrantedly assert the inevitability of a certain scientific result. Any given result of scientific enquiry implicitly relies upon a complex range of different conditions-material, social, and intellectual-and these are the products, as Hacking puts it, of a 'distinctive and historically formed organisation' (2000, p. 3). There is a vast and worthy body of work in the history of the sciences that documents the complexities and contingencies that attended the emergence of modern scientific enterprises-including, for instance, its cognitive values, investigative technologies, disciplinary structures, interdisciplinary relations, and even its very identity as 'science'. Those diverse historical stories are, furthermore, shaped and guided by wider contingent intellectual and cultural developments-the Protestant Reformation, romanticism, the Cold War, and so on. The historian, Stephen Gaukroger, for example, is almost halfway through a quintet of studies devoted to 'the emergence of a scientific culture', a story whose scope and depth surely reflects its description, not of iron necessities, but of fragile contingencies.

The point is that scientific enquiry is, in Andy Pickering's words, always situated within a 'specific material-conceptual-disciplinarysocial-etc. space' that could have been quite different (1995, p. 185). Unless one is a disciple of Hegel, such possibilities cannot be ruled out, for two reasons. The first is the ample documentary evidence

\footnotetext{
6 See, e.g., Hacking (2000), p. 59, Radick (2005), p. 24, and Soler (2008), p. 225

7 The two volumes published so far are The Emergence of a Scientific Culture and The Collapse of Mechanism and the Rise of Sensibility, covering the periods 12101685 and 1680-1760, respectively. See Gaukroger (2006, 2010).
} 
provided by historians and sociologists of science that indicates the role of chance, contingency, and fortune in various scientific endeavours; if so, things could have been different, even if one cannot perhaps say any more than that. Presumably that much is conceded even by those who judge counterfactual enquiries-understood, here, as enquiry into those possible alternative histories-to be 'parlour games with might-have-beens', as E.H. Carr famously complained (1961, p. 97). The judgement that history could have gone another way does not need to be justified by any further account of how it might otherwise have gone.

These remarks on the complexity and contingency of the background conditions for scientific enquiry help to set up my first criticism of inevitabilism. This is directed, recall, at the following slightly revised claim:

$\left(\mathrm{H} 2^{*}\right)$ It is possible to determine, in principle or in practice, the inevitability of certain results of scientific investigation.

Given the remarks just cited, what this requires, in practice, is that the inevitabilist can successfully perform a whole range of epistemic tasks: including, for instance, those required for determining the inevitability of the whole array of practices, concepts, social structures, and so on, that provide the 'spaces' and 'cultural background' of the projects of scientific enquiry that produced the results for that the inevitabilists wants to assert inevitability. Given the range and complexity of these multiply-stacked levels of contingency it should be clear that, as David E. Cooper puts it, 'none of us even approximates to being such a creature, equipped with such magisterial powers of knowledge' (2010, §5A). These epistemic tasks, in fact, become even more complex once one further factors in the 'topography' of historical contingency; for instance, the fact that contingency comes in degrees, changes over time, is subject to 'scaling effects', and so on. ${ }^{8}$

Confronted with a charge of hubris, the inevitabilists could, of course, instead opt to make highly qualified conditional claims about the inevitability of certain scientific results-for instance, by arguing that 'if $a b c . . . n$ obtain, then result $\mathrm{R}$ is inevitable'. But this, of course, entails either triviality or hubris: in the former case, their position collapses into a form of contingentism, while in the latter case, they must pretend to be able to determine the inevitability of the background conditions-and thus incur the charge of hubris. To say that inevitabilist claims are hubristic is not the same as saying that they are false. It is only to say that one cannot be warranted in making assertions about their truth or falsity either way. This point has been repeated by many commentators on contingency and scientific realism, including Radick and Hacking. ${ }^{9}$

It emerges, then, that inevitabilist claims are epistemically hubristic. In the next section, I argue that the same is true of their PUSU objection.

\section{The PUSU objection, and an impasse}

The contingentist stances that are the natural rivals to inevitabilism can take weaker or stronger forms, with the latter being, of course, that different histories would have produced different scientific results. Both forms are, however, confronted with the same objection, which, in Hacking's cheerfully direct phrasing, goes: 'put up or shut up. Show us an alternative development' (2000, p. 67).

Hacking illustrates the PUSU objection with the example of Evelyn Fox Keller's suggestions about the possibility that the notion of the genetic code as 'master controller of the nature of the

\footnotetext{
8 See Inkpen and Turner (2012).

9 See, e.g., Radick (2005), p. 24 and Hacking (1999), p. 80 and (2000), p. 70
}

organism' was, in fact, 'purely contingent', such that 'we need not have had that controlling idea at all (cf. Hacking, 2000, pp. 6970). ${ }^{10}$ The emergence and entrenchment of that 'controlling idea' was a contingent direction that the history of biology has taken, for instance, owing to the modelling of nature upon prevailing social arrangements reflecting extensive and entrenched gender biases. If those social conditions had been different, then a very different biology could have emerged. But, at this point, the PUSU objection comes into play: if Keller wants to talk about alternative possibilities for biological science, then she must either put up, by describing those alternatives, how they might have emerged, their development and implications, and so on-or, of course, 'shut up' about them. ${ }^{11}$

Since the PUSU objection takes the form of a choice-to 'put up' or 'shut up'-it can be seen to rely upon an implicit presupposition. This is that it is actually possible, both in practice and in principle, for the contingentist to attempt to 'put up', for this is the basis of its status as a challenge. Call this the put-up presumption (PUP) and note that, like $\mathrm{H} 2 \mathrm{a}$, it implicitly entails the possibility that one could 'put up' alternatives to whatever scientific result or theory is being considered.

My aim, in this section, is to argue that PUP is suspect because it is incompatible with the practical and social realities of scientific enquiry (a point pre-empted by the earlier remarks, in Section 2, on the complexity and contingency of its background conditions). It is probably truistic to state that the performance of scientific enquiry, of whatever form, requires at least three things: enormous expenditure of resources, prolonged periods of time, and a community of enquirers. Indeed, these features are the definitive characteristics of contemporary 'Big Science'. ${ }^{12}$ Given these facts, it is effectively impossible, in practice if not in principle, for a contingentist (or even a community of them) to produce an alternative scientific theory or tradition independently of such resources, time, and community.

Yet this is, in fact, what PUP requires-for instance, if the challenge to Keller is to 'put up' an alternative molecular biology, guided by its own 'controlling idea', and so on. The incompatibility of PUP with the practical and social realities of scientific enquiry is neatly stated by Emiliano Trizio. He points out that the 'hopelessly collective and highly specialised character of enquiry prevents, in practice, any private reconstruction of the entire edifice of knowledge' (2008, p. 258). That 'edifice' was, after all, the result of the collective cognitive and practical labours of generations of socially organised enquirers, and it would, in my vocabulary, be a form of epistemic hubris to pretend that an alternative 'edifice' could be constructed without the requisite expenditure of time and resources. Indeed, it is a form of epistemic humility to recognise such facts of epistemic dependence. ${ }^{13}$

PUP is, therefore, epistemically hubristic, for it consists of the demand upon contingentists that they successfully perform a 'private reconstruction' of the inherited 'edifice of knowledge'. Since that edifice was, of course, a product of the cognitive and practical efforts of a temporally extended community of enquirers, such a demand could only be tenable if one had good reason to suppose that contingentists possessed magisterial epistemic capacities: ones that enabled them to reproduce the efforts of an entire scientific research programme. Such a supposition is, of

\footnotetext{
10 See, e.g., Keller $(1985,1995)$.

11 For a related criticism of PUSU, see Soler (2014). I am grateful to Léna for sharing a draft of this paper with me, and for her comments on mine.

12 See, e.g., Galison and Hevly (1992) and Nye (1997).

13 On epistemic dependence and the collective nature of scientific enquiry, see de Ridder (2014)
} 
course, absurd, and so PUP emerges as intrinsically epistemically hubristic: given our actual epistemic capacities, it is, both in practice and in principle, impossible to 'put up'. But this seems to play into the inevitabilists' hands: for it appears to be a concession on the contingentists' part that they cannot make good on their talk of the alternative theories and results that history, had it gone another way, could have produced.

This inevitabilist response is too quick, however, for it does not follow from the fact that the contingentist cannot produce an alternative that no such alternatives exist. To make that move would be to presuppose that the space of epistemic possibilities is equal to, or capable of being exhausted by, the contingentist's epistemic powers-and as Kyle Stanford has remarked, in a different though related context, our 'cognitive constitutions [are] not well-suited to that task' (2006, p. 45). ${ }^{14}$ Indeed, the very fact that scientific enquiry requires increasingly vast practical and cognitive labours is a proof of this. Stanford goes on to propose that there could be 'cognitive supercreatures' who are able, at a glance, to imagine and produce alternative theories, but-with admirable understatement-notes that 'the evidence suggests that we are simply not cognitive creatures of this kind' (2006, p. 45). The fact that one cannot 'put up' therefore does not indicate that there is nothing to 'put up'. It instead shows only that our capacity to 'put up' is conditioned by a range of material, social, and intellectual conditions that are contingent and, therefore, do not always obtain. So we arrive, once again, back at contingentism.

The PUSU objection is, then, not a real objection, but a fait accompli. It takes the putative form of a choice-to 'put up' or 'shut up'-but, on analysis, only allows the contingentist to shut up. The reason is that its core presupposition, that it is actually possible to produce alternative theories and traditions, relies upon a hubristic estimation of the contingentists' epistemic powers: these being the powers to circumvent the practical and social realities of scientific enquiry by successfully achieving a 'private reconstruction' of the 'edifice of knowledge'. This does entail, of course, that the contingentist cannot produce the alternatives to which they gesture, but this does not-for the reasons given-indicate that no such alternatives exist.

It appears at this point that an impasse has been reached. On the one hand, the inevitabilist cannot secure their claims about the inevitability of certain of the results of scientific investigation-on pain of hubris. But, on the other hand, it seems that the contingentist cannot secure their claims about the possibility that 'other histories' could have led to 'other sciences'-again, on pain of hubris.

The discussion reaches an impasse, a fact noted by commentators. Hacking, for instance, notes that his own remarks on the topic of contingency and inevitability as 'deliberately non-conclusive' (2000, p. 58). Radick, similarly, suggests that taking seriously contingency might require 'either the surrendering of ... or, as it could well turn out, a surrendering to' our 'stubborn realist intuitions' (2005, p. 47). Perhaps the most striking statement of the impasse is offered by Trizio: '[we] have to accept the existing science, without being able to rule out the possibility that it would have been different if the decisions of our predecessors had been different. And there is no way to prove that our predecessors had no choice, but to do what they did' (2008, p. 258). In these remarks, one sees another form that epistemic humility can take: recognition that, on certain topics, no confidence is possible.

Interestingly, Trizio goes on to further characterise the impasse using a language of epistemic humility. There is a "certain feeling of powerlessness' when we are 'faced with the immense heritage of

\footnotetext{
14 See, further, Kidd (2013).
}

scientific knowledge, we can neither produce an alternative to a considerable part of it, nor persuade ourselves of the inevitability of its results' (2008, p. 258). There is epistemic humility, too, in the recognition that one is often powerless to resolve a problem and also in accepting the fact of one's powerlessness. But, in this case, a way out of the impasse is possible: for our choice is not between inevitabilism and contingentism, since the former, as a hubristic stance, is not one actually available to us. Instead, our choice is between different forms of contingentism.

Consider, for instance, Trizio's remark that we must accept the existing science-of quarks, genes, and so on-while, at the same time, being unable to prove that any other forms of science were or are possible. Put another way, we know that certain scientific theories and results are possible, but what we do not, and cannot, know is whether only these theories and results are possible; this is why, for A.W. Moore, 'true modesty means focussing on ... the distinction between what we do know and what we do not'; this is, he adds, enough to 'check our hubris' (1997, p. 251).

A due sense of epistemic humility requires that we embrace some form of contingentism, and therefore focus upon the real question facing us: how contingentist ought we be?

\section{Contingency, historiography, and the 'sense of inevitability'}

This question has been discussed by a range of philosophers of science and of history-including those inspired by Ben-Menahem (1997) and Tucker (1999)_and it has been the subject of several recent studies in counterfactual history of science. ${ }^{15}$ A useful way to consider the question is to look at some contingentist historiographies of science, specifically, Radick's work on the history of biology, and Hasok Chang's work on the history of chemistry.

In several recent papers, Radick argues that, had history gone differently, the twentieth century could have inherited non-genic biologies; perhaps one developed from the world of the biometrician W.F.R. Weldon, as Radick has suggested. ${ }^{16}$ If so, then other histories could have led to other biologies. Similarly, Chang argues that phlogistonian chemistry could have persisted as a serious rival to oxygen theory, especially once exaggerated claims about its merits vis-à-vis it rival are dismantled. ${ }^{17}$ Many others, of course, could be cited, including, most recently, Peter Bowler's book Darwin Deleted (2012); but Radick and Chang's cases are among the best developed, not least since they have gone to some lengths to provide additional empirical support for their claims. ${ }^{18}$

Since it would take more space than is available to detail, let alone discuss, these cases, let me instead draw attention to a cluster of methodological points made by both Radick and Chang. Other candidate case studies are a matter for another time, as is a consideration of potential inevitabilist replies.

These methodological points concern certain obstacles to claims about the contingency of science-and hence to any efforts to engage with the question of how contingentist our stance on its history ought to be. Speaking of the history of biology, Radick complains that the "weight of presumption has traditionally come down so much on the side of gene inevitabilism ... that gene contingentism has hardly had a look' (2005, p. 26). A certain sense

\footnotetext{
15 A useful starting point is Weinryb (2009).

16 See, e.g., Radick $(2012,2013)$ and Radick and Jamieson (in press).

17 See, e.g., Chang (2009, 2010).

18 A good example is Radick's ongoing 'Genetics Pedagogies Project', which uses a specially developed counterfactual undergraduate biology syllabus to explore how students' sense of the inevitability of deterministic biologies can be affected by curricular changes and pedagogical practice. See, further, Jamieson and Radick (2013). I am grateful to Annie Jamieson for helpful discussion of the project, and regret that only a little of it made its way into the final paper.
} 
of inevitability has emerged that has gradually stifled recognition of the contingencies of the history of biological enquiry, and any impetus to engage in relevant forms of counterfactual enquiry. ${ }^{19}$

Radick goes on to note that, as a consequence, the first job of those who wish to explore gene contingentism is to work hard to 'dissolve some prejudices about taking it seriously, since 'no' looks so obvious' (2008, p. 44). It might seem, for instance, given the practical and cognitive successes of genic biology, that the idea of equivalently successful non-genic biologies might seem obviously absurd. Radick emphasises, however, that this thought is not a result of careful comparison of the cognitive and other merits of genic and non-genic biologies-for no such comparisons have taken place. Instead, Radick suggests that the thought reflects the activity of implicit prejudices therefore act to subtly reduce the credibility of contingentist possibilities. This has the further consequence of lends them a self-sustaining character, presumably hence Radick's description of them as 'stubborn realist intuitions' (2005, p. 47).

Turning to the history of chemistry, Chang warns of similar 'prejudices' that act as obstacles to the serious consideration of contingentist possibilities. These include the dangers of submitting to an 'unreflective triumphalism' that automatically 'celebrates the winning side in an episode, whichever it may happen to be' (2009, p. 240). Such 'Whiggish' triumphalism is objectionable because its commitment is to whichever side 'wins' rather than to the 'best' side - the most empirically adequate theory, say-which are not, in every case, the same thing. Chang argues that such historiographical attitudes are suspect because they implicitly exclude the role that contingency plays in the success or failure of scientific enquiry. Unreflective triumphalism aims to celebrate the winning side, but unless they suppose the winning side is inevitable, their commitment to any particular theory is entirely promiscuous; their slogan is 'Three cheers for the inevitable victory of [insert theory here]!'

Moreover, Chang notes that triumphalist celebrations often rely upon tacit appeals to a background 'scientific worldview' that is founded on premises', such as the reality of genes or the compound nature of water, that are in contestation (2012, p. 4). If this is so, then the deep confidence that is reflected in triumphant declarations about the inevitability of certain scientific results is grounded in the very background worldview that presupposes those results. This ignores what Chang (2012, p. 4) calls the 'truly pluralistic challenge' of trying to 'step outside that worldview', by either identifying, or in some cases retrieving, alternative developmental pathways.

The methodological points offered by Radick and Chang can be expressed as a suspicion of a strategy of justifying the exclusion of contingentism by appeal to a tacit and pre-reflective sense of inevitability. Certainly many writers on the historical contingency of the sciences often invoke some form of this idea, including Hacking's observation that inevitabilist assertions are not empirical discoveries made on the basis of enquiry, but rather tacit appeals to a 'built-in sensibility ... that arises in a great many people in Western civilization' (1999, p. 79).

One line of thought can be found in a set of remarks offered by Ludwig Wittgenstein, who was very sensitive to the contingency of our concepts, practices, 'language-games', and so on. In a note written around 1940, Wittgenstein described one of his 'most

\footnotetext{
19 There may also be contingentist prejudices in historiography of science, for instance in some social constructionist writings (see, e.g., Rorty, 1989, p. 16). I think such prejudices exist, but also think that inevitabilist prejudices have been more influential in historiography of science. Still, if contingentist prejudices are becoming more influential, all the better for my advocacy of contingentism. I think [x] for this point.
}

important methods' as being 'to imagine a historical development of our ideas different from what has actually occurred' (1998, p. 45). The value of this method lies partly in the fact that it protects us against a lapse into the sort of confident assertions of historical necessity that fuel a sense of inevitability. Wittgenstein complained that the 'insidious thing' about this 'causal point of view' (as he called it) is that it prompts us to say, "'Of course, it had to happen like that"', rather than to think 'it may have happened like that and also in many other ways' (1998, p. 45). Worse still, once a sense of inevitability becomes attached to a particular idea or practice it 'elbows all others aside' so that they seem 'paltry, preliminary stages at best', and to combat this, one must 'climb down to the sources', before the entrenchment of fixed estimations of what ought to be 'disregarded [and] preferred' (1998, p. 69). The call is to abandon the 'causal point of view' and suspend a sense of inevitability, thereby disabling the 'prejudices' and 'sensibilities' that underwrite inevitabilist confidence.

The appeal to a sense of inevitability is not a form of argument, but instead subtly exploits our implicit predispositions to certain claims and conclusions-evident in the talk of 'intuitions' and 'sensibilities', say. To use a useful term offered by Steven Shapin, a sense of inevitability can introduce implicit 'credibility handicaps' into the space of epistemic possibilities, such that, to take one example, the very idea that genic biologies were not inevitable comes to seem incredible. The fact that our sense of the space of epistemic possibilities is structured by an implicit economy of credibility is not, in itself, a bad thing. In fact, it serves useful cognitive purposes, given the fact that it makes our organisation of, and movement through, that space more efficient.

But worries ought to arise when it is forgotten that those implicit credibility assignments are not always the result of deliberation and enquiry. Certain claims and conclusions-the inevitability of genic biology, say-may, in fact, 'enjoy a credibility advantage by virtue of being high-toned versions of locutions already present-in some form and in some degree-in lay culture' (Shapin, 2010, p. 28). The fact that 'locutions' concerning genic conceptions of biology should be automatically enjoy a 'credibility advantage' is unsurprising in a culture that recently celebrated 'The Century of the Gene', to cite the title of a book by Keller (2002). But then the worry is that the justificatory work is being done by locutions, prevailing ways of thinking and talking, that are not, in fact, justified. The space of epistemic possibilities that we inhabit therefore tacitly relies upon 'a whole raft of qualifications, reservations, and stipulations about context and contingency [that have] to be ... taken for granted' (Shapin, 2010, p. 339).

The critical task of identifying and critically assessing our implicit judgements of credibility was a purpose of the methodologies noted earlier. Such strategies include, inter alia, Wittgenstein's method of imagining alternative historical developments, Chang's criticisms of historiographical 'triumphalism', and Radick's attempts to 'dissolve ... prejudices' through careful counterfactual enquiry. Their common purpose is to prompt critical recognition of the role that implicit credibility attributions play in our engagement with the sorts of epistemic possibilities offered by contingentist stances on the history of science. If so, such strategies are doubly epistemically humble. First, they invite us to critically enquire into the grounds of our confidence when making certain claims - in this case, about the inevitability of certain scientific results, and the concepts, methods, practices, and so on upon which they are contingent. A sense of inevitability is, after all, a poor basis for any inference to inevitability, even if such inferences are, as Chang and Wittgenstein noted, very tempting.

Second, they enable us to identify and take seriously alternative epistemic possibilities - in this case, other ways that the history of scientific enquiry might have gone-that might afford us a clearer 
view of the complexity and contingency of that endeavour. Indeed, our capacity to imagine counterfactuals is intimately related to our capacity for rationality, so asking 'What if...', in the context of the history of science, is an extension of our cognitive capacities rather than an eccentric employment of them-for the sake of 'parlourgames', say. ${ }^{20}$ The adoption of a contingentist stance is therefore in accordance with a due sense of epistemic humility, and is to be recommended for that reason.

In the next and final section, let me offer some possibilities for how one might answer the question of how contingentist we ought to be.

\section{Deep contingencies}

A useful way to enquire into the scope or strength of the contingentist positions we might employ is to identify some of the stronger positions that frame that debate. This strategy has been popular with many philosophers interested in the topic of historical contingency - of the scientific enterprise, moral heritage, sociopolitical norms, and so on. My focus in this section is on two 'deep contingencies' that are relevant to our appraisals of the modern sciences, and the following discussion is informed by several figures, but is largely inspired by Cooper (2002: ch. 8, 2010). ${ }^{21}$

The first deep contingency pertains to the possibility that an alternative account of the world might have become entrenched-one too different, in its laws and ontology, to count as a natural scientific account. Many candidates are offered by the history of philosophy, including, inter alia, Leibniz's monadology, Berkeley's idealism, and the cosmologies of the will offered by Schopenhauer and Nietzsche (see Cooper, 2002, p. 193f). It is, obviously, the scientific vision of the world that is today entrenched, but two points should be noted about its entrenchment. The first is that it might not have happened: a whole range of factors-cultural, environmental, political, and so on-could have prevented its emergence and entrenchment.

Many early advocates for the sciences were acutely aware of such obstacles to their ambitions, including Sir Francis Bacon. The aphorisms in Book One of the New Organon document several obstacles to the establishment of his envisioned collective project of scientific enquiry: well-established rival projects for the 'study of nature'; the social and intellectual faults he dubbed 'Idols of the Mind', and the lack of institutional support for collective scientific endeavour. $^{22}$

Such obstacles were, of course, considerable, and the fact that they were overcome does not indicate that they were destined to be. In fact, Bacon's confidence in the establishment of science was arguably grounded, at least in part, in a religious sense of himself as a witness to, if not an agent of, 'a new era in the history of mankind' (Rossi, 1968, p. 37). Such convictions can help to offset worries about deep contingency, but they also reflect and sustain an acute awareness of it-our consolations invariably reflect our concerns.

The second point more directly invokes the earlier theme of epistemic humility, and is stated by Cooper as follows:

'[T]he failure of any rival to the scientific image to become our entrenched view was not due to the recognition, after patient and prolonged investigation, that the entities and processes

\footnotetext{
20 For an engaging discussion of empirical studies concerning counterfactuals, psychology, and rationality, see Byrne (2005).

${ }^{21}$ As Léna Soler pointed out to me, a virtue of referring to these contingencies as 'deep' rather than 'radical'-my original term-is that something only appears radical in contrast to a contingent context.

22 See, further, Peltonen (1999), chs. 1 and 6.
}

postulated by the rivals did not pass muster in comparison with those proposed by physics [...] The fact is that no one has ever tried, in detail, to develop the 'research programmes' indicated by such rival images of reality, or to compare them, in terms of explanatory scope, with those of the natural sciences' (Cooper, 2002, p. 194)

The claim here is not that these rival images would have sustained equally successful projects of enquiry, by criteria not in dispute, but rather that no judgements can be made either way. ${ }^{23}$ For to make such judgements would, to recall earlier terminology, require one to perform a range of epistemic tasks for which we lack the requisite capacities; for instance, 'to survey such rivals, to work out their implications, [and] to compare them with one another and with our entrenched scientific account' (Cooper, 2002, p. 195).

Similarly, Feyerabend argued that judgements about the putatively inevitable triumph of one scientific theory were, too often, hubristic. Such judgements typically involve the pretence that we had 'gone through all possible trials' and so achieved, even approximately, 'an overall view of reality', on which basis magisterial judgements about the fortunes and failures of theories could be made (1991, p. 516). The first deep contingency therefore reflects the possibility that an alternative account of the world could have emerged and become entrenched, and that this is a possibility that can neither be denied nor ruled out, on pain of hubris.

The second deep contingency concerns the possibility that our culture-or 'form of life'-could have been one unreceptive to scientific enquiry. Several figures have defended versions of this claim, but let me confine myself to just three. First, Edmund Husserl $(1970, \S 33)$ argued that the achievements of science are grounded in a particular 'surrounding world of life', a 'life-world (Lebenswelt), that lends intelligibility and salience to its various constitutive activities. But this supporting life-world is contingent, and had it been different, the contexts of practical and cognitive interests upon which scientific enquiry depend could have failed to obtain. Second, Feyerabend, in his later writings, argued that the 'basic moves' that help to 'establish' a scientific culture consist in 'asserting a certain form of life', within which scientific purposes and practices 'resonate' (2001, p. 79). But had those moves either not been made, or been tried but failed, then our scientific culture might not have emerged, even if something else would have.

And third, Hacking argues that the 'family of questions that makes sense' in a given society depends, partly, upon its guiding concerns and interests (2000, p. 70). If early Europeans had, for instance, 'had other interests'-soteriological, say, or aesthetic-then perhaps 'after the fifteenth century C.E. human beings did nothing we would call science at all'; perhaps we might have become a 'Zen' culture (2000 p. 58). These various suggestions reflect an awareness of the deep contingency of our 'entire cultural background'(Henry, 2008, p. 552) and, hence, of the idea of scientific enquiry as a cognitively and culturally compelling enterprise.

The claim here is that a whole array of background conditions requisite for scientific enquiry are contingent, including, at this point, not simply particular concepts and methods, but a deeper set of concerns, interests, and enthusiasms. It is not, says David M. Knight, 'obvious that anyone should do [science] or take it very seriously', not least since it was, especially in its early days, perceived as 'a component of culture'-alongside art, music, religious observance-rather than a necessary or definitive feature of a culture. Indeed, for many people, for many years, 'connoisseurship,

\footnotetext{
${ }^{23}$ In this paper, I suspend issues concerning the idea of alternative scientific theories that are both genuine and successful, but for helpful discussions, see French (2008), Hacking (2000), pp. 62-63 and Soler (2008, 2014).
} 
discrimination and wisdom were more important culturally than scientific knowledge' (2009, pp. 1 and 238). It should take little exercise of the historical and anthropological imagination to recognise that human beings have, at different times and in different places, been driven by a strikingly diverse range of 'ground-projects', to use the term offered by Bernard Williams (1981: ch.1). ${ }^{24}$

Many of these projects will of course confer intelligibility and cogency, if not urgency and priority, upon scientific enquiry, but very many of them would not. Imagine, say, soteriological forms of life that esteem and pursue only those activities and experiences with a bearing the achievement of salvation. ${ }^{25}$ Since there are ample instances of such forms of life, not least from earlier stages of our own cultural history, their possibility cannot be denied. ${ }^{26} \mathrm{~A}$ critic might concede this, of course, but quickly insist that their members were not engaged in enquiries into the nature of reality-as scientific enquiry is-but this begs the question, and ignores the fact that the reflective members of those forms of life did provide accounts of the nature of reality. Indeed, the intelligibility of, say, soteriological projects are typically undergirded by a particular metaphysical system, as in Hinduism and Buddhism. ${ }^{27}$

Here, then, are two deep contingencies that might serve to provide a basis for further future discussions of the range of stances that one might in debates about the contingency of the scientific enterprise. Such possibilities of course raise a great range of issues-only some of them discussed here-but my purpose was to sketch these options, saving the task of giving fuller accounts of them for another time. It is, however, briefly worth responding to a possible objection to such appeals to deep contingencies: namely that no one really denies the possibility that, if history had gone this way rather than that way, nothing like a 'scientific culture' could have arisen. Our history is, after all-to recall the subtitle of Gaukroger (2006) — that of the 'emergence of a scientific culture', a phrasing which offers two points: the first, noting the indefinite article, is that our scientific culture could have been different; the second is that it might not have emerged at all. To take seriously such deep contingencies is, then, an opportunity to reflect critically on our historiographical practices and our epistemic attitudes, and so is a good exercise in epistemic humility.

Certainly the abandonment of inevitabilist stances on our science and its history might serve to liberate us from undue optimism and restore to our attention a range of questions-about the origins, development, status, and future of science-that ought to be raised and reflected upon the members of a society for whom science is the dominant cognitive and cultural authority. ${ }^{28}$

\section{Conclusions}

This paper used the epistemic concepts of humility and hubris to provide a framework for critical reflection on the competing merits of 'inevitabilist' and 'contingentist' stances on the history of science. My conclusion is that a properly humble sense of the scope and strength of our epistemic capacities indicates that we are confined to a range of contingentist stances, of different degrees of strength. A good place to start when adjudicating between these stances is to consider several deep contingencies - and, in a spirit of humility, to see how we go from there.

\footnotetext{
${ }^{24}$ Though I lack the space, here, to engage the question of how one might assess and adjudicate between such diverse conceptions of the good life. See the very different answers offered by, e.g., Kekes (2000), Kitcher (2012), and Rawls (1999). 25 See, e.g., Cooper (2002), pp. 131 and 200.

${ }^{26}$ A good example, discussed by Cooper (2000, p. 200), is the 'Last Judgement' culture described by Wittgenstein (1967), pp. 53-54.

27 See, for instance, Harvey (2013), ch. 3.

${ }^{28}$ See, further, Kidd (2015).
}

\section{References}

Ben-Menahem, Y. (1997). Historical contingency. Ratio, 10, 99-107.

Bowler. (2012). Darwin deleted: Imagining a world without Darwin. Chicago: University of Chicago Press.

Byrne, R. M. J. (2005). The rational imagination: How people create alternatives to reality. Cambridge, MA: MIT Press.

Carr, E. H. (1961). What is history? London: Macmillan.

Chang, H. (2009). We have never been Whiggish (about phlogiston). Centaurus, 51, 239-264.

Chang, H. (2010). The hidden history of phlogiston: How philosophical failure can generate historiographical refinement. Hyle, 16(2), 47-79.

Chang, $\mathrm{H}$. (2012). Is water $\mathrm{H}_{2} \mathrm{O}$ ? Evidence, realism, pluralism. Dordrecht: Springer.

Cooper, D. E. (2002). The measure of things: Humanism, humility, and mystery. Oxford: Clarendon Press.

Cooper, D. E. (2010). Contingency and the absolute conception of science. Paper delivered at the workshop 'Science, Contingency, and Pluralism'. Durham University, 30 November.

Feyerabend, P. (1991). Concluding unphilosophical conversation. In G. Munévar (Ed.), Beyond reason: Essays on the philosophy of Paul Feyerabend (pp. 433-448). London: Kluwer.

Feyerabend, P. (1993). Against method (3rd ed.). London: Verso.

Feyerabend, P. (2001). Conquest of abundance: A tale of abstraction versus the richness of being, B. Terpstra (Ed.) Chicago: University of Chicago Press.

French, S. (2008). Genuine possibilities in the scientific past and how to spot them. Isis, 99, 568-575.

Galison, P., \& Hevly, B. (1992). Big science: The growth of large-scale research. Stanford, CA: Stanford University Press.

Gaukroger, S. (2006). The emergence of a scientific culture: Science and the shaping of modernity, 1210-1685. Oxford: Oxford University Press.

Gaukroger, S. (2010). The collapse of mechanism and the rise of sensibility: Science and the shaping of modernity, 1680-1760. Oxford: Oxford University Press.

Hacking, I. (1999). The social construction of what? Cambridge, MA: Harvard University Press.

Hacking, I. (2000). How inevitable are the results of successful science? Philosophy of Science, 67, 58-71.

Harrison, P. (2007). The fall of man and the foundations of science. Cambridge: Cambridge University Press.

Harvey, P. (2013). An introduction to Buddhism: Teachings, history, and practices (2nd ed.). Cambridge: Cambridge University Press.

Henry, J. (2008). Ideology, inevitability, and the scientific revolution. Isis, 99, 552-559.

Husserl, E. (1970). The crisis of European sciences and transcendental phenomenology. Evanston, IL: Northwestern University Press.

Inkpen, R., \& Turner, D. (2012). The topography of historical contingency. Journal of the Philosophy of History, 6, 1-19.

Jamieson, A. \& Radick, G. (2013). Putting Mendel in his place: How curriculum reform in genetics and counterfactual history of science can work together. In K. Kampourakis (Ed.), The philosophy of biology: A companion for education (pp. 577-595). Dordrecht: Springer.

Kekes, J. (2000). Pluralism in philosophy: Changing the subject. Cornell: Cornell University Press.

Keller, E. F. (1985). Reflections on gender and science. New Haven, CT: Yale University Press.

Keller, E. F. (1995). Reconfiguring life: Metaphors of twentieth-century biology. New York: Columbia University Press.

Keller, E. F. (2002). The century of the gene. Cambridge, MA: Harvard University Press.

Kidd, I. J. (2013). Unconceived alternatives and epistemic humility. Paper delivered at the conference 'Unconceived Alternatives and Scientific Realism'. Durham University, 2 July.

Kidd, I. J. (2015). What's so great about Feyerabend: Against Method, forty years on. Metascience, 24, 3 (in press)

Kitcher, P. (2012). Science in a democratic society. New York: Prometheus.

Kinzel, K. (2015). State of the field: Are the results of science contingent or inevitable? Studies in History and Philosophy of Science, 52, 55-66.

Knight, D. M. (2009). The making of modern science: Science, technology, medicine and modernity: 1789-1914. Cambridge: Polity.

Langton, R. (1998). Kantian humility: Our ignorance of things in themselves. Oxford: Clarendon.

Moore, A. W. (1997). Points of view. Oxford: Oxford University Press.

Nye, M. J. (1997). Before big science: The pursuit of modern chemistry and physics, 1800-1940. London: Prentice Hall.

Peltonen, M. (1999). The Cambridge companion to Bacon. Cambridge: Cambridge University Press.

Pickering, A. (1995). The mangle of practice: Time, agency, and science. Chicago: University of Chicago Press.

Radick, G. (2005). Other histories, other biologies. In A. O'Hear (Ed.), Philosophy, biology, and life (pp. 21-47). Cambridge: Cambridge University Press.

Radick, G. (2008). Counterfactuals and the historian of science. Focus section of Isis 99. Radick, G. (2012). Scientific inheritance: How history matters for the sciences. Inaugural professorial lecture, 16 May, University of Leeds, podcast available at http://www.personal.leeds.ac.uk/ phlgmr/.

Radick, G., \& Jamieson, A. (Eds.). (2015). W. F. R. Weldon's theory of inheritance (1904-1905 (in press) 
Rawls, J. (1999). The law of peoples, with "the idea of public reason revisited". Cambridge, MA: Harvard University Press.

de Ridder, J. (2014). Epistemic dependence and collective scientific knowledge. Synthese, 191(1), 37-53.

Rorty, R. (1989). Contingency, irony, and solidarity. Cambridge: Cambridge University Press.

Rossi, P. (1968). Francis Bacon: From magic to science. Chicago: University of Chicago Press.

Sankey, H. (2008). Scientific realism and the inevitability of science. Studies in History and Philosophy of Science, 39, 259-264.

Shapin, S. (2008). The scientific life: A moral history of a late modern vocation. Chicago: University of Chicago Press.

Shapin, S. (2010). Never pure: Historical studies of science as if it was produced by people with bodies, situated in time, space, culture, and society, and struggling for credibility and authority. Balitmore, MD: The John Hopkins University Press.

Soler, L. (2008). Are the results of our science contingent or inevitable? Studies in History and Philosophy of Science, 39, 221-229.
Soler, L. (2014). The "put-up-or-shut-up" inevitabilist demand: Why contingentists should not care. Unpublished manuscript.

Stanford, K. (2006). Exceeding our grasp: Science, history, and the problem of unconceived alternatives. Oxford: Oxford University Press.

Trizio, E. (2008). How many sciences for one world? Contingency and the success of science. Studies in History and Philosophy of Science, 39, 253-258.

Tucker, A. (1999). Historiographical counterfactuals and historical contingency. History and Theory, 38, 264-276.

Weinryb, E. (2009). Historiographic counterfactuals. In A. Tucker (Ed.), A companion to the philosophy of history and historiography (pp. 109-119). Oxford: WileyBlackwell.

Williams, B. (1981). Moral luck: Philosophical papers, 1973-1980. Cambridge: Cambridge University Press.

Wittgenstein, L. (1967). Lectures and conversations on aesthetics, psychology and religious belief (C. Barrett Ed.) Berkeley: University of California Press.

Wittgenstein, L. (1998). Culture and value (P. Winch, Trans), (G.H. von Wright and H. Nyman, Eds.). Oxford: Blackwell. 